PLEASE NOTE! THIS IS SELF-ARCHIVED VERSION OF THE ORIGINAL ARTICLE

To cite this Article: K. Kuparinen (2017) KEEPING UP WITH THE NURSES - ON-THE-JOB LANGUAGE COACHING OF HEALTH CARE PROFESSIONALS OF IMMIGRANT BACKGROUND, ICERI2017 Proceedings, pp. 477-480.

doi: $10.21125 /$ iceri.2017.0193

URL: https://library.iated.org/view/KUPARINEN2017KEE 


\title{
KEEPING UP WITH THE NURSES - ON-THE-JOB LANGUAGE COACHING OF HEALTH CARE PROFESSIONALS OF IMMIGRANT BACKGROUND
}

\author{
Kristiina Kuparinen \\ Laurea University of Applied Sciences (FINLAND)
}

\begin{abstract}
Language skills are of crucial importance for the immigrants. When employed, however, there are often little opportunities to learn the occupational language more in depth. This article focuses on changes that take place when professional language and communication training is implemented by individual coaching on the job instead of formal training in a classroom. The scene of the changes is a pilot training of a project called Career path.
\end{abstract}

Coaching was selected as the method of the training due to four principles that differ from traditional frontal teaching: the focus is on individuality, professional development, involvement of the work community and flexibility of the implementation. This is to say that the primus motor of the training is the nurse - she or he has the ownership of learning.

The article discusses the experiences of implementing the principles above. The paper also presents some of the feedback of the participants of the pilot.

Keywords: Vocational language training, health care, coaching.

\section{INTRODUCTION}

Let us begin by peeking into a room where a doctor's round is taking place: there are several professionals gathered to discuss a patient's situation. If we listen carefully, we can observe that the majority language of the country is a minority language in this room. Even though immigration of skilled work force is a newish phenomenon in Finland, a hospital in a big city displays us the working environment of today and tomorrow - there will be less and less limits to the mobility of professionals.

This article seeks to find out how language training should change in order to serve future specialists needed for challenging jobs. As a possible solution, the article presents a pilot of a training of vocational Finnish that was organized for nurses of immigrant background at the metropolitan area of Finland, in Vantaa. The pilot was enabled by European Social Fund (ESF) funding to a project called Career Path (2015-2018).

Paramount to the first implementation of this way of training was also co-operation with health care sector of the city of Vantaa. The surroundings were ideal for the experimentation, as statistics show that health care professionals of immigrant background in many cases work in primary health care and elderly care. [1] The voice of the nurses involved in the pilot is conveyed to this paper by their citations. The source of the citations are the semi-structured interviews conducted with each participating nurse at the end of the training in December 2016.

As well as in many other countries, there is an ongoing discussion of the appropriate name for the language training of a specific field. The training presented in here applies methodology of LSP (Language for Special Purposes). In English, the most precise name could be On-the-job language coaching for reasons described below.

\section{THE USER POINT OF VIEW OF THE LANGUAGE}

The training tackles the challenges of the nurses of immigrant background in health care working environments according to four principles. First, the focus is on vocational communication, secondly the coaching pays attention to individual needs, and finally it aims at affecting the whole community at the workplace as well as saving time and costs by flexible use of the nurses' working hours.

The coaching takes place at each nurse's workplace and the procedure begins with the trainer's visit to the unit of the nurse taking part in the pilot. The purpose of the visit is to get to know the 
environment and the routines. Expectations and individual aims are discussed with the nurse and her/his head nurse.

Most frequently, the nurses have expressed their need of support in certain situations, such as coping on the phone or in interaction with the patients' relations. In terms of producing texts, the participants have mainly wished to get more self-confident in their everyday documentation. A recent study has shown that shortages of fluency, complexity and accuracy are quite possible even though the nurse would be up to her demanding everyday tasks and communication. [2]

The nurses' point of view plays an important role in defining the special features of their vocational communications. The participants' perspective is considerable wider than that of native speakers: based on the nurses' expressions the professionals' crucial language skills consist of managing a variety of nursing situations and being able to produce multiple documents. As a participant formulated: "Language is involved in everything - in security and in relations." The big picture is parallel to frameworks that describe core competences in language studies in Nursing Degree programs. [3]

In other words, there are features of standard language in vocational language and the skill manifests itself in vocational situations. Hence, the training rules out no features of standard language, nor are vocational issues only seen as pieces of vocabulary or grammar. The aim of the coaching has been supporting the nurses to more natural and fluent communication.

From the point of view of an outsider, i.e. the language coach, there are significant differences in different surroundings and various tasks within healthcare. Considering this as well as the participant's diverse strengths and development needs, the starting point and the aims of coaching is different for each nurse.

\section{TRUST IS OF THE ESSENCE}

When studying at school, it is rather easy to anticipate the actions of the teacher. As the coach arrives to a workplace, the situation is quite different and it needs to be carefully clarified to the participants. The participants might see the trainer assessing their performance or even having doubts of their professional skills. Therefore, it is important to emphasize the action as a possibility to deepen one's communicative skills in authentic situations with the help of a professional in linguistics. A dialogue in these situations requires mutual trust and motivation - if the needs are defined rather by the head nurse than the participant herself, there will probably be poor conditions for functional co-operation.

On each visit, the coach observes the nurse's actions - obviously with every respect to the clients' and patients' privacy. The purpose of the observations is to screen for critical points in the interaction for elaboration. After each situation, the nurse and the coach reflect the strong points of this encounter as well as discuss the linguistic and communicative features that might be done differently. In order to support the nurse's professional identity it is crucial to also pay attention to the parts of communication that were fluent.

Many of the nurses wished to have the support of the coach at the end of the shift, while documenting. The questions and discussions around writing often dealt with structural issues and the accuracy of terms and vocabulary. "You made the examples according to my difficulties. I even found some new words and that's good." Also the differences between standard language and its' spoken variations often need clarification. The arrangement provides dialogue between a specialist of health care and the one of language. The setting is ideal to learning, as the actions take place on the zone of proximal development - the nurse succeeds almost independently and the purpose of the co-operation is to support the professional to manage the communication on her or his own [4] and thus the coaching is both meaningful and adequate.

The primus motor of the coaching are the needs and the aims of the nurse. However, the role of the coach extends itself to observing and analyzing the communications in the working environment. In other words, the coaching is also about discussing the social conduct in the community. There might for example be shortages in encountering a patient during custodial care, if the convention in the nurse's previous working environment hasn't involved any talking at all. In a case like this, the nurse can be guided to listen and observe the other nurses coping in the same kind of situations. The observations will then be discussed together with the coach. Making observations is an important skill, as it provides the opportunity to widen the affordances in the workplace which in its' turn is a key to future language development. [5] "I learn every day. I observe others - this is how she did it." 
In order to work according to the principles described above, the trainer needs to be flexible and open to new situations. As a specialist, the trainer also needs to be able to pick up and analyze the linguistic and communicative elements of the working environment. A teacher of a language cannot become a specialist of every field but there certainly needs to be willingness to learn about the profession. [6] On one hand this approach is demanding, on the other hand getting involved in authentic situations deepens the teacher's knowledge, as there often is little chances of working side by side with health care professionals. This added knowledge enriches the community of the teacher, as current and meaningful issues can be dealt with also within other programs. [7]

\section{THE WORKING COMMUNITY AS A LEARNING ENVIRONMENT}

In our pilot the coach visits each nurse's working place according to individual needs. The length of the visits depends on the nurse's duties and the ongoing situation at the unit. The number of the visits can vary - the project has enabled approximately eight visit per participant. One of the aims of the project is that the coaching is noticeable to all members of the community in order to enhance discussions about linguistic support. This is important, as the common belief is that language studies can only take place outside - and before - the workplace. [8]

Even though the nurse with an immigrant background might have a strong professional identity, consciousness of possible flaws in language skills can create uncertainty. [9] However, the nurses found it easy to ask for help and consult a colleague, if one is self-initiative. According to the participants, nobody will correct misspelling or other structural error even though the same mistake would be written down on every shift. As the perception of language and professional are intertwined, it is important to pay attention how this kind of situations are dealt with. A coach at the workplace can facilitate this discussion.

Nurses of diverse career path gain the trust of the community with their professional skills and actions. [9] Even though there might be shortages in his or her language skills, it is possible to cope with their duties by the support of previous experience. It is significant for the learning that the working place and community provide opportunities for social interaction. When professional communication is used in meaningful contexts, it opens up wide linguistic resources for the learner. Members of the working community have a strong influence on a professional. [10]

In other words, community fosters communication skills - one could even state that the majority of professional language learning takes place at the workplace, with the support of the colleagues. [11]

\section{A FLEXIBLE SCHEDULE IS A DEMANDING LUXURY}

The work of a nurse is hectic and consuming. One of the objectives of the pilot was to find a way to lessen the burden of the participants. As there is evidence of fatigue affecting the learning results, if the training is organized outside working hours [7], the nurses in our pilot were able to attend the coaching on their working hours. With an efficient way of making use of time, the pilot has also aimed at diminishing employer's loss of time and costs.

The participants of the pilot valued the arrangements. "Keep on going! It helps a lot - it's almost luxury." However, the demand of flexible hours is hard to fulfill, as the nurses work in shifts, they might be the only ones with certain skills or authorizations, they need to react to emergencies - as well as fall ill and need some holiday as everyone else. As one of the nurses put it: "You can plan your own schedule - for the nurse, however, it will not always come off." In order to construct a coherent training under these circumstances, a close co-operation with the head nurse will be of the essence. Even considering this, finding the good time for both the nurse and the coach proved to be the most vulnerable feature of the training.

\section{CONCLUSION}

There seems to be remarkable benefits in having the working life as a learning environment. The demands of the job keep up the motivation, the needs of communication are easy to observe and it is also quite easy to follow up the progress. [7]

There are myriads of demands of communicative skills in nurses' everyday actions. One needs to be able to give comfort and clarifications to the relations of the patients as well as convey information to other professionals in an accurate way. One has to know one's way in producing documents quite 
efficiently. There are different kind of conventions on each unit and working community. In order to get the skilled professionals of immigrant background to the service of the society even in linguistically demanding jobs, there needs to be ways of supporting them along their career paths, also after the threshold level.

Due to the experiences of the pilot, it seems that classroom teaching has major restrictions in its' ability to serve educated immigrants. "It's [taking part in coaching] different from being on a course; the teacher has something that you might not need." As a learning environment, the class is a closed setting - the opposite of the world where globalization is melting down the borderlines. [11] We need changes that can help professionals of immigrant background on their steps by the career path.

The pilot has promoted three kind of changes. From the point of view of the trainer, there was an emphasis of authenticity and dialogue. The experience also widened the perspective of nurses' professional communications. For the nurses this on-the-job coaching saved time and for the community it opened up discussions of linguistic support. The principle of flexibility proved to be the most demanding, and it needs to be elaborated as the project progresses. As a whole, the experience of the pilot was rewarding. The pilot was a learning environment for us all, and the project wishes to thank City of Vantaa, all the understanding patients and clients and of course the nurses that took the writer as a part of their demanding day.

\section{REFERENCES}

[1] A.-M. Aalto, M. Elovainio, T. Heponiemi, L. Hietapakka, H. Kuusio \& R. Lämsä. Ulkomaalaistaustaiset lääkärit ja hoitajat suomalaisessa terveydenhuollossa. Haasteet ja mahdollisuudet. Helsinki: National Institute of Health and Welfare, 2013.

[2] M. Seilonen \& M. Suni. Ulkomailta palkatut sairaanhoitajat ammatillista suomen kielen taitoaan osoittamassa. University of Jyväskylä, 2016.

[3] J. Komppa, T. Jäppinen, T. Herva \& T. Hämäläinen. Korkeakoulutuksen ammatilliset suomi toisena kielenä -viitekehykset. Helsinki, Metropolia UAS, 2014.

[4] M. Suni. Toista kieltä vuorovaikutuksessa. Kielellisten resurssien jakaminen toisen kielen omaksumisen alkuvaiheessa. Jyväskylä Studies in Humanities 94. Doctoral Thesis. University of Jyväskylä, 2008.

[5] A.Virtanen. Toimijuutta toisella kielellä. Kansainvälisten sairaanhoitajaopiskelijoiden ammatillinen suomen kielen taito ja sen kehittyminen työharjoitteluissa. Jyväskylä Studies in Humanities 311. Doctoral Thesis. University of Jyväskylä, 2017.

[6] Z. Antic. Teacher Education in English for Special Purposes. Scientific Journal of the Faculty of Medicine in Niš. 33 (3) 211 - 215, 2016.

[7] D. Belcher. Trends in Teaching English for Special Purposes. Annual Review of Applied Linguistics 24, 165 - 186, 2004.

[8] J. Komppa. Työnantajan odotukset, työntekijän vastuu ja työyhteisön tuki. Näkökulmia korkeakoulutettujen maahanmuuttajien ammatillisen suomen oppimiseen. In (Kalliokoski, J., K. Mård-Miettinen \& T. Nikula) Kieli koulutuksen resurssina: vieraalla ja toisella kielellä oppimisen ja opetuksen näkökulmia. AFinLA-e. Soveltavan kielitieteen tutkimuksia n:o 8. 168-185, 2015.

[9] A. Virtanen. Käsityksiä kansainvälisesti rekrytoitujen hoitajien ammatillisesta kielitaidosta ja sen kehittymisestä. Mediakeskusteluiden ja asiantuntijan haastattelun analyysia. Puhe ja kieli, 31:4, 153-172, 2011.

[10] M. Strömmer. Material scaffolding: Supporting the comprehension of migrant cleaners at work. European Journal of Applied Linguistics. 4.2., 239-274, 2016.

[11] J. Rosen \& S. Bagga-Gupta. Prata svenska, vi är i Sverige! [Talk Swedish, we are in Sweden!]: A study of practiced language policy in adult language learning. Linguistics and Education. Volume 31, $59-73,2015$. 